\section{(1)}

CrossMark

\title{
Integration of drug safety monitoring in tuberculosis treatment programmes: country experiences
}

\author{
Edine Tiemersma (10 ${ }^{1}$, Susan van den Hof ${ }^{1,2}$, Gunta Dravniece ${ }^{1}$, Fraser Wares ${ }^{1}$, \\ Yohannes Molla ${ }^{3}$, Yusie Permata ${ }^{4}$, Endang Lukitosari ${ }^{5}$, Mamel Quelapio (1) 1 , \\ Si Thu Aung ${ }^{6}$, Khay Mar Aung ${ }^{7}$, Hoang Thanh Thuy ${ }^{8}$, Vu Dinh Hoa $\mathbb{1}^{9}$, \\ Merkinai Sulaimanova $^{10}$, Saadat Sagyndikova ${ }^{11}$, Mavluda Makhmudova ${ }^{12}$, \\ Alijon Soliev ${ }^{12}$ and Michael Kimerling (i) ${ }^{1}$
}

\begin{abstract}
Affiliations: ${ }^{1}$ KNCV Tuberculosis Foundation, Den Haag, the Netherlands. ${ }^{2}$ Centre for Infectious Disease Epidemiology and Surveillance, National Institute for Public Health and the Environment, Bilthoven, the Netherlands. ${ }^{3} \mathrm{KNCV}$ Tuberculosis Foundation, Addis Ababa, Ethiopia. ${ }^{4} \mathrm{KNCV}$ Tuberculosis Foundation, Jakarta, Indonesia. ${ }^{5}$ National Tuberculosis Program, Ministry of Health, Jakarta, Indonesia. ${ }^{6}$ Dept of Public Health, Ministry of Health and Sports, Yangon, Myanmar. ${ }^{7} \mathrm{FHI} 360$, Yangon, Myanmar. ${ }^{8}$ National Tuberculosis Program, Ministry of Health, Hanoi, Vietnam. ${ }^{9}$ National Centre of Drug Information and Adverse Drug Reactions \& Hanoi University of Pharmacy, Hanoi, Vietnam. ${ }^{10} \mathrm{KNCV}$ Tuberculosis Foundation, Bishkek, Kyrgyzstan. ${ }^{11}$ National Tuberculosis Program, Ministry of Health, Bishkek, Kyrgyzstan. ${ }^{12}$ KNCV Tuberculosis Foundation, Dushanbe, Tajikistan.
\end{abstract}

Correspondence: Edine Tiemersma, KNCV Tuberculosis Foundation, Benoordenhoutseweg 46, Den Haag 2596BC, the Netherlands. E-mail: edine.tiemersmalakncvtbc.org

@ERSpublications

Active drug safety monitoring and management (aDSM) is being recommended by the World Health Organization for new drugs and regimens for drug-resistant tuberculosis. Early experience with aDSM shows that collaboration and capacity building of pharmacovigilance and TB programmes are crucial http://bit.ly/2meWkiV

Cite this article as: Tiemersma E, van den Hof S, Dravniece G, et al. Integration of drug safety monitoring in tuberculosis treatment programmes: country experiences. Eur Respir Rev 2019; 28: 180115 [https://doi. org/10.1183/16000617.0115-2018].

ABSTRACT New drugs and shorter treatments for drug-resistant tuberculosis (DR-TB) have become available in recent years and active pharmacovigilance (PV) is recommended by the World Health Organization (WHO) at least during the early phases of implementation, with active drug safety monitoring and management $(\mathrm{aDSM})$ proposed for this. We conducted a literature review of papers reporting on aDSM. Up to 18 April, 2019, results have only been published from one national aDSM programme. Because aDSM is being introduced in many low- and middle-income countries, we also report experiences in introducing it into DR-TB treatment programmes, targeting the reporting of a restricted set of adverse events (AEs) as per WHO-recommended aDSM principles for the period 2014-2017. Early beneficial effects of active PV for TB patients include increased awareness about the occurrence, detection and management of AEs during TB treatment, and the increase of spontaneous reporting in some countries. However, because PV capacity is low in most countries and collaboration between national TB programmes and national PV centres remains weak, parallel and coordinated co-development of the capacities of both TB programmes and PV centres is needed.

Provenance: Submitted article, peer reviewed.

Received: 17 Dec 2018 | Accepted after revision: 09 Sept 2019

Copyright $\odot$ ERS 2019. This article is open access and distributed under the terms of the Creative Commons Attribution Non-Commercial Licence 4.0. 


\section{Introduction}

New drugs and more effective and/or shorter regimens for the treatment of drug-resistant tuberculosis (DR-TB) have recently become available. Multidrug-resistant tuberculosis (MDR-TB) is the resistance of Mycobacterium tuberculosis to the two most potent first-line drugs: rifampicin and isoniazid. Because rifampicin is the most potent drug, and rifampicin resistance (RR) does not often occur without concomitant isoniazid resistance, RR-TB is often seen as a proxy for MDR-TB. A shorter (9 months) treatment regimen (STR) for RR-/MDR-TB without additional resistance or intolerance against the key second-line anti-TB drugs [1-5] is now available and, for RR-/MDR-TB that cannot be treated with the STR, new drugs such as bedaquiline (Bdq) $[6,7]$ and delamanid (Dlm) $[8,9]$ and repurposed drugs including clofazimine, linezolid (Lzd) and carbapenems can be added to a longer, individualised regimen.

In clinical trials, Bdq has been associated with hepatotoxicity and QT prolongation in a small proportion of patients $[6,10]$. An unexplained increased mortality rate found in the intervention arm of a phase IIb trial compared to the placebo arm [6] has not, however, been reported in later publications [10-20], including use in children [21], in regimens combining Bdq and Dlm [15, 22, 23] or with use of Bdq beyond the recommended 24 weeks [12]. A systematic review concluded that Bdq is well tolerated, with only $3.5 \%$ of patients discontinuing treatment because of an adverse event (AE), and in only $0.6 \%$ did this concern QT prolongation [24]. Dlm has been associated with mild QT prolongation but is generally well tolerated, including by children $[8,9,25-31]$.

The safety profiles of repurposed drugs when used in multidrug regimens for a lengthy period are not yet fully understood [32]. Safety analysis from the STREAM trial showed that although there was a higher mortality rate among those receiving the STR compared to those receiving the standard 20-month regimen, especially among patients co-infected with HIV, this difference was not statistically significant. QT prolongation and liver enzyme abnormalities were more often reported from the study arm than the control arm [33]. Lzd seems to be among the most effective of the repurposed drugs, but in randomised controlled trials (RCTs) as well as non-randomised studies, Lzd has frequently been associated with myelosuppression and peripheral neuropathy, leading to the discontinuation of $\operatorname{Lzd}$ in $6 \%-23 \%$ of patients $[34,35]$.

Because of the paucity of safety data for new/repurposed drugs and regimens (ND\&R), the World Health Organization (WHO) has recommended their use under strictly controlled conditions, i.e. with active pharmacovigilance (PV) in place $[7,9]$. PV is defined by the WHO as the "science and activities related to the detection, assessment, understanding and prevention of AEs or any other possible drug-related problems" [36]. The most comprehensive method of active PV is cohort event monitoring (CEM) [37]. However, CEM requires systematic reporting and review of all AEs experienced within the respective patient cohort, irrespective of their seriousness, severity or clinical significance. Because at least $70 \%$ of RR-/MDR-TB patients experience one or more AEs during treatment [38-42], CEM would be too resource intensive, especially in settings where there are serious human resource constraints, inadequate patient support mechanisms and weak PV systems [43]. To enable active PV for ND\&R conducted in a less labour-intensive form, in July 2015 WHO developed a simpler framework for active TB drug safety monitoring and management (aDSM) [44]. The guidance document reinforces the core programmatic management of DR-TB recommendation of active and systematic monitoring of common AEs as part of correct patient management, provides guidance on the recording and reporting of AEs using a tiered approach, and recommends coordination of aDSM activities with existing in-country PV structures [44]. Three aDSM packages were proposed: the core package, reporting all serious adverse events (SAEs); the intermediate package, reporting all SAEs plus AEs judged to be of special interest; and the advanced package, reporting all AEs of clinical significance, which may in fact almost approximate to full CEM [44]. AEs judged to be of special interest should be reported independent of seriousness, severity or causality, and include peripheral neuropathy (paraesthesia), psychiatric disorders and central nervous system toxicity, optic nerve disorder (optic neuritis) or retinopathy, ototoxicity, myelosuppression (including anaemia), prolonged QT interval, lactic acidosis, hepatitis, hypothyroidism, hypokalaemia, pancreatitis, phospholipidosis and acute kidney injury (acute renal failure).

In this paper, we discuss early experiences with aDSM and similar methods of active PV for ND\&R in TB programmes.

\section{Why active drug safety monitoring?}

Monitoring and management of AEs has been recommended by the WHO since 2006 [45]. The careful recording of clinical aspects and actions taken, including the identification and management of AEs, is an intrinsic component of good clinical practice [46] and is included in the International Standards of TB Care [47]. A systematic overview of the occurrence of (common) AEs, and the drugs with which these are treated, is needed to allow the procurement of ancillary drugs to be carefully planned [48]. Furthermore, surveillance of AEs is needed to detect and describe rare AEs [49] that cannot be detected in the 
small-scale clinical trials on which most (conditional) approvals from drug regulatory authorities are based. Clinical trials do not always include specific sub-populations such as children, pregnant and lactating women, the elderly and patients with comorbidities [8,50], nor cover all geographical regions with a high burden of DR-TB. Specific populations may require specific dosing and may have altered drug responses compared to the patients included in phase II trials [51]. The lack of drug safety data leads to limited understanding of the burden of AEs due to anti-TB treatment and the net benefit of treating DR-TB and extensively drug-resistant (XDR)-TB, i.e. MDR-TB with additional resistance to second-line injectable drugs and fluoroquinolones, given that it remains unknown to what extent the occurrence of AEs leads to unfavourable treatment outcomes (such as untimely death, treatment failure) and loss to follow-up, especially in resource-constrained countries where the TB burden is highest [52] and detection and clinical management expertise and options more limited.

Many countries have a system of spontaneous reporting of AEs using Individual Case Safety Reports (often referred to as the "yellow form" or "yellow card" system) available from the Council for International Organizations of Medical Sciences (www.cioms.ch). Currently, this form is the only internationally recognised format; however, many different variants of spontaneous AE reporting forms are being used (e.g. [53]). In practice, spontaneous reporting rarely occurs [54, 55], notably for TB. This indicates a lack of knowledge among healthcare workers about the existence of PV authorities, proper cross-training and basic awareness of the importance of this work. Adequate collaboration between public health programmes and medicine regulatory authorities is often lacking [43, 56-58]. In 2011 and 2012 respectively, only four of 46 sub-Saharan African countries [43] and one of five Asian countries [57] included in regional situational analyses had a PV system functionally able to detect, evaluate and prevent medicine safety issues. TB programmes, in particular, had not undertaken active surveillance of AEs. It should be noted that these assessments were done some years ago; the requirement of implementing active $\mathrm{PV}$ for patients on ND\&R is forcing changes to this landscape (e.g. www.fhi360.org/sites/default/files/ media/documents/resource-pv-workshop-report.pdf), although strong collaborations between the national TB programme (NTP) and the national PV centre (NPVC) have not always been established [58].

\section{Active drug safety monitoring in resource-constrained settings}

aDSM as recommended by the WHO is now being implemented in most countries with a relatively high burden of RR-/MDR-TB [52], with the support of local and international partners such as the WHO, the KNCV Tuberculosis Foundation (KNCV), Médecins Sans Frontières, Partners in Health, FHI360, Management Sciences for Health, the Union and PATH, and external funding (e.g. from the United States Agency for International Development and the Global Fund Against AIDS, Tuberculosis and Malaria). aDSM envisions real-time recording and reporting of AEs, i.e. prospective data collection. Data are collected nationally, mostly by NTPs.

Collection in a global database is currently conducted through at least four different mechanisms. First, following pre-existing legal mechanisms, in some countries (e.g. Tanzania and Indonesia) AE reports are transferred to the regular PV authorities, which assess them and submit suspected adverse drug reactions (ADRs) to the Uppsala Monitoring Centre that has hosted the WHO programme for international drug monitoring (www.who-umc.org) since 1978. SAGWA et al. [59] have assessed the association between ototoxicity and the use of aminoglycosides and capreomycin in TB treatment, but this study only included reports up to June 2014, i.e. before aDSM was recommended. Two publications from the Nigerian PV programme about AEs in (MDR-)TB treatment were based on reports in their national PV database [60, 61], also before implementation of aDSM in their country. Second, specifically for the surveillance of AEs in the scope of aDSM, the WHO Global TB Programme with the Special Programme for Research and Training in Tropical Diseases has developed the global aDSM database (www.who.int/tdr/research/tb_hiv/adsm/en/) [62]. By the end of January 2019, 16 countries had reported a total of 891 AEs to this database (C. Halleux, personal communication). Third, 27 countries that reportedly faced difficulties in submitting data to the global aDSM database have committed to report to the recently implemented Global TB Network hosted by the World Association for Infectious Diseases and Immunological Disorders (www.waidid.org/) [63, 64]. So far, 18 countries have shared data, which were planned for publication in the second quarter of 2019 [64]. Finally, while the mechanisms noted above are done on a voluntary basis, the Global Drug Facility (www. stoptb.org/gdf/), which provides quality-assured drugs globally including Bdq and Dlm, requires mandatory reporting of all SAEs among those patients receiving Bdq and/or Dlm through the Global Drug Facility.

Apart from two conference abstracts from Belarus in 2016 [65, 66], up to April 2019 no results on the frequency and type of AEs reported through aDSM had been published. However, there are a limited number of reports on prospectively collected data on AEs in patients treated with ND\&R in programmatic settings $[14,17,18,23,67-70]$. These eight reports describe partially overlapping cohorts (table 1). Four reports on three cohorts describe the safety and efficacy of regimens containing Bdq [14, 17, 18, 69], 


\begin{tabular}{|c|c|c|c|c|c|c|c|c|c|c|c|}
\hline $\begin{array}{l}\text { First author } \\
\text { [ref.] }\end{array}$ & Location & Setting & $\begin{array}{l}\text { Patient } \\
\text { enrolment } \\
\text { period }\end{array}$ & Patients $\mathrm{n}$ & $\begin{array}{l}\text { Patient age } \\
\text { years }\end{array}$ & Patient type & Drug or regimen & $\begin{array}{l}\text { Patients receiving } \\
\text { ND\&R n }\end{array}$ & Patients with SAE & $\begin{array}{l}\text { Patients with drug(s) } \\
\text { interrupted or } \\
\text { withdrawn }\end{array}$ & $\begin{array}{l}\text { Patients with any } \\
\text { type of } A E\end{array}$ \\
\hline BASTARD [67] & $\begin{array}{l}\text { Maputo, } \\
\text { Mozambique }\end{array}$ & $\begin{array}{l}\text { Prospective data } \\
\text { collection from } \\
\text { MSF-supported } \\
\text { project }\end{array}$ & $\begin{array}{l}\text { Nov 2015-May } \\
2018\end{array}$ & 19 & NR & Pulmonary MDR-TB & $\begin{array}{l}\text { STR with } \mathrm{Km} \text { shifted } \\
\text { to Bdq after a } \\
\text { median of } \\
2.8 \text { months } \\
\text { because of } \\
\text { ototoxicity }(n=17), \\
\text { nephrotoxicity or } \\
\text { hypokalaemia }\end{array}$ & $\begin{array}{l}19 \text { STR with Bdq } \\
\text { instead of Km }\end{array}$ & NR & $\begin{array}{l}0 \% \text { after shifting from } \\
\mathrm{Km} \text { to Bdq }\end{array}$ & $\begin{array}{l}\text { “No grade } 3 / 4 \text { QT } \\
\text { prolongation or AST/ } \\
\text { ALT increase" } \\
\text { Other AEs NR }\end{array}$ \\
\hline HAFKIN [68] & Global & $\begin{array}{l}\text { Prospective data } \\
\text { collection from } \\
\text { compassionate use } \\
\text { programme for } \\
\text { Dlm (Otsuka with } \\
\text { ERS, WHO, MSF } \\
\text { and PiH) }\end{array}$ & $\begin{array}{l}\text { Feb 2014-Jun } \\
2016\end{array}$ & 78 & $8-59$ & $\begin{array}{l}\text { Pulmonary } \\
\text { MDR-TB: MDR } \\
\text { (8), pre-XDR (26), } \\
\text { XDR (44) }\end{array}$ & $\begin{array}{l}\text { Individualised } \\
\text { regimens with Dlm }\end{array}$ & $\begin{array}{l}78 \text { Dlm with\# } \\
\text { Lzd (60/66) } \\
\text { Cfz (50/66) } \\
\text { carbapenems (33/66) } \\
\text { Bdq (12/66) }\end{array}$ & $\begin{array}{l}\text { NR } \\
10.3 \% \text { died during } \\
\text { Dlm course, none } \\
\text { attributed to Dlm }\end{array}$ & $\begin{array}{l}\text { Dlm: } 2.6 \% \text { temporary, } \\
1.3 \% \text { permanently } \\
\text { (all QT } \\
\text { prolongation) }\end{array}$ & $\begin{array}{l}\text { QTcF }>500 \mathrm{~ms}: 3.8 \% \\
\text { attributable to Dlm, Cfz } \\
\text { land Bdq in } 1 / 3, \text { or } \\
\text { hypokalaemia in } 2 / 3 \text { ) } \\
\text { Other AEs NR }\end{array}$ \\
\hline HAFKIN [23] & Global & $\begin{array}{l}\text { Prospective data } \\
\text { collection from } \\
\text { compassionate use } \\
\text { programme for } \\
\text { Dlm (Otsuka with } \\
\text { ERS, WHO, MSF } \\
\text { and } \mathrm{PiH} \text { ) }\end{array}$ & $\begin{array}{l}\text { Feb 2014-Feb } \\
2018\end{array}$ & 84 & $\geqslant 6$ & $\begin{array}{l}\text { MDR (4), pre-XDR } \\
(18), \text { XDR (62) }\end{array}$ & $\begin{array}{l}\text { Individualised } \\
\text { regimens with Dlm } \\
\text { and Bdq }\end{array}$ & $\begin{array}{l}84 \text { Bdq+DIm with: } \\
\text { Lzd (77) } \\
\text { Cfz (66) } \\
\text { carbapenems (33/66 } \\
\text { on Cfz) }\end{array}$ & $\begin{array}{l}\text { NR } \\
12 \% \text { died not related } \\
\text { to } \mathrm{Dlm} / \mathrm{Bdq}\end{array}$ & $\begin{array}{l}\text { Bdq: } 1 \% \text { interrupted } \\
\text { then Cfz withdrawn } \\
\text { due to } \\
\text { QTcF }>500 \mathrm{~ms}\end{array}$ & $\begin{array}{l}\text { QT prolongation: } 6 \% \\
\text { QTcF }>500 \mathrm{~ms}: 1 \% \\
\text { Other AEs NR }\end{array}$ \\
\hline NoJekA [14] & $\begin{array}{l}5 \text { sites across } \\
\text { South Africa }\end{array}$ & $\begin{array}{l}\text { Prospective } \\
\text { programmatic data } \\
\text { collection including } \\
\text { SAE; interim } \\
\text { analyses after } \\
\geqslant 1 \text { month of } \\
\text { treatment }\end{array}$ & $\begin{array}{l}\text { Mar 2013-Aug } \\
\quad 2014\end{array}$ & 91 & $\geqslant 18$ & $\begin{array}{l}\text { (Pre-IXDR-TB: } \\
\text { MDR+FQ-R (41), } \\
\text { MDR+SLID-R } \\
\text { (16), XDR (34) }\end{array}$ & $\begin{array}{l}\text { Individualised } \\
\text { regimens with Bdq }\end{array}$ & $\begin{array}{l}91 \text { Bdq with: } \\
\text { Lfx (76) } \\
\text { Lzd (64) } \\
\text { Cfz (68) }\end{array}$ & $\begin{array}{l}10 \% \geqslant 1 \text { SAE } \\
1 \% \text { atrial fibrillation } \\
\text { (attributed to Bdq) } \\
3 \% \text { severe psychosis, } \\
\text { mood disorder and } \\
\text { delusion } \\
3 \% \text { died }\end{array}$ & $\begin{array}{l}\text { Bdq: } 1 \% \text { due to atrial } \\
\text { fibrillation }\end{array}$ & $\begin{array}{l}\text { QTcF }>500 \mathrm{~ms}: 3 \% \\
\quad \text { (attributed to } \mathrm{Bdq} \text { ) } \\
\text { QTcF }>50 \mathrm{~ms} \text { from BL: } 26 \% \\
\text { Other AEs NR }\end{array}$ \\
\hline NoJeKa [17] & $\begin{array}{c}7 \text { sites across } \\
\text { South Africa }\end{array}$ & $\begin{array}{l}\text { Prospective } \\
\text { programmatic data } \\
\text { collection including } \\
\text { SAE; analysis of } \\
\text { final treatment } \\
\text { outcomes }\end{array}$ & $\begin{array}{l}\text { Mar 2013-Mar } \\
2015\end{array}$ & 200 & $\geqslant 18$ & $\begin{array}{l}\text { (Pre)-XDR-TB: } \\
\text { MDR+FQ-R (87), } \\
\text { MDR+SLID-R } \\
\text { (33), XDR (78), } \\
\text { unknown (2) }\end{array}$ & $\begin{array}{l}\text { Individualised } \\
\text { regimens with Bdq }\end{array}$ & $\begin{array}{l}200 \text { Bdq with: } \\
\text { Lfx (166) } \\
\text { Lzd (128) } \\
\text { Cfz (164) }\end{array}$ & $\begin{array}{l}32 \% \geqslant 1 \text { SAE; } \\
\text { Attributed to Bdq: } 5 \% \\
\text { of all } 87 \mathrm{SAE} \\
\text { (QTCF>500 ms), } \\
\text { Anaemia: } \mathrm{n}=12 \text { (14\% } \\
\text { of SAE) } \\
\text { Peripheral } \\
\text { neuropathy: } \mathrm{n}=9 \\
\text { (10\%) } \\
\text { Ototoxicity: } \mathrm{n}=7(8 \%) \\
\text { 12.5\% died }\end{array}$ & $\begin{array}{l}11 \% \text { Bdq interrupted, } \\
\text { in only one case } \\
\text { due to AE other } \\
\text { than QT- } \\
\text { prolongation }\end{array}$ & $\begin{array}{l}\text { Any: } 86 \% \\
\text { Attributed to Bdq: } 3.2 \% \\
\text { (n=19) of all } 603 \text { AEs: } \\
\text { QTcF } 5500 \mathrm{~ms}: \mathrm{n}=5,0.6 \% \\
\text { overall } \\
\text { QTcF } 505 \mathrm{~ms} \text { from } \mathrm{BL}: \mathrm{n}=8 \\
\text { (1.3\%) } \\
\text { Atrial flutter: } \mathrm{n}=1(0.2 \%)\end{array}$ \\
\hline
\end{tabular}




\begin{tabular}{|c|c|c|c|c|c|c|c|c|c|c|c|}
\hline $\begin{array}{l}\text { First author } \\
\text { [ref.] }\end{array}$ & Location & Setting & $\begin{array}{l}\text { Patient } \\
\text { enrolment } \\
\text { period }\end{array}$ & Patients $\mathrm{n}$ & $\begin{array}{l}\text { Patient age } \\
\text { years }\end{array}$ & Patient type & Drug or regimen & $\begin{array}{l}\text { Patients receiving } \\
\text { ND\&R n }\end{array}$ & Patients with SAE & $\begin{array}{l}\text { Patients with drug(s) } \\
\text { interrupted or } \\
\text { withdrawn }\end{array}$ & $\begin{array}{l}\text { Patients with any } \\
\text { type of } A E\end{array}$ \\
\hline Olayanju [18] & $\begin{array}{l}1 \text { site in South } \\
\text { Africa }\end{array}$ & $\begin{array}{l}\text { Prospective cohort of } \\
\text { patients on } \\
\text { programmatic } \\
\text { treatment with/ } \\
\text { without Bdq }\end{array}$ & $\begin{array}{c}\text { Jan 2008-Sep } \\
2014 \text { (non-Bdq); } \\
\text { Nov 2013-Apr } \\
2016 \text { (Bdq) }\end{array}$ & 272 & NR & $\begin{array}{l}\text { Lab-confirmed } \\
\text { XDR-TB }\end{array}$ & $\begin{array}{l}\text { Individualised } \\
\text { regimens with/ } \\
\text { without Bdq }\end{array}$ & $\begin{array}{l}68 \text { Bdq with: } \\
\text { Lzd (55) } \\
\text { Cfz (67) } \\
\text { Mer (1) } \\
204 \text { no Bdq with: } \\
\text { Cfz (2) }\end{array}$ & $\begin{array}{l}\text { NR } \\
15 \% \text { died on Bdq vs } \\
13 \% \text { on non-Bdq } \\
\text { regimens }(p<0.05)\end{array}$ & $\begin{array}{l}\geqslant 1 \text { drug withdrawn } \\
\text { due to } A E: 59 \% \\
\text { Bdq vs } 38 \% \\
\text { non-Bdq (p<0.05) } \\
\text { Bdq withdrawn: } 0 \% \\
\text { Lzd withdrawn: } \\
33 \% \\
\text { PAS withdrawn: } 16 \% \\
\text { Cm withdrawn: } 86 \% \\
\text { Cs withdrawn: } 13 \%\end{array}$ & $\begin{array}{l}\text { Any AE: } 96 \% \text { Bdq (vs } 70 \% \\
\text { non-Bdq group) } \\
\text { AE in Bdq group occurring } \\
\text { at >10\% frequency": } \\
\text { QT prolongation: } 10 \% \text { lall } \\
<500 \mathrm{~ms} \text { ) } \\
\text { Peripheral neuropathy: } \\
22 \% \\
\text { Dizziness/disorientation: } \\
16 \% \\
\text { Hearing impairment: } 43 \% \\
\text { (vs } 15 \% \text { ), } \\
\text { Abdominal pain: } 22 \% \\
\text { Vomiting: } 24 \% \\
\text { Nausea: } 24 \% \\
\text { Skin reaction: } 29 \% \\
\text { Arthralgia: } 19 \% \\
\text { Body pains: } 28 \% \\
\text { Anaemia: } 21 \% \text { (vs } 1 \% \text { ) } \\
\text { Nephrotoxicity: } 21 \%\end{array}$ \\
\hline SARIN [69] & India & $\begin{array}{l}\text { Prospective } \\
\text { programmatic data } \\
\text { collection in the } \\
\text { National Institute } \\
\text { of TB and } \\
\text { Respiratory } \\
\text { Diseases }\end{array}$ & Unclear & 290 & $\geqslant 18$ & $\begin{array}{l}\text { MDR-TB: MDR (2), } \\
\text { MDR+FQ-R (214), } \\
\text { MDR+SLID-R } \\
\text { (14), XDR (60) }\end{array}$ & $\begin{array}{l}\text { Semi-standardised } \\
\text { regimens with Bdq }\end{array}$ & $\begin{array}{l}290 \text { Bdq with: } \\
\text { Mfx Hd (116) } \\
\text { Lzd (261) } \\
\text { Cfz (249) }\end{array}$ & $\begin{array}{l}\text { NR } \\
22 \% \text { died }\end{array}$ & $\begin{array}{l}\text { Bdq interrupted: } 16 \% \\
\text { (due to QT } \\
\text { prolongation) } \\
\text { Bdq withdrawn: } 1 \% \\
\text { (due to QT } \\
\text { prolongation) }\end{array}$ & $\begin{array}{l}\text { Any AE: } 38 \% \\
\text { QTcF } 480-500 \mathrm{~ms}: 13 \% \\
\text { QTcF > } 500 \mathrm{~ms}: 4 \% \\
\text { AEs occurring at }>10 \% \\
\quad \text { frequency: } \\
\text { Peripheral neuropathy: } \\
\quad 14 \% \%^{+} \\
\text {Dermatological: } 10 \%^{+} \\
\text {Haematological: } 10 \%^{+}\end{array}$ \\
\hline SARIN [70] & India & $\begin{array}{l}\text { Prospective } \\
\text { programmatic data } \\
\text { collection for } \\
\text { patients on Bdq } \\
\text { +Dlm salvage } \\
\text { regimens in the } \\
\text { National Institute } \\
\text { of TB and } \\
\text { Respiratory } \\
\text { Diseases }\end{array}$ & $\begin{array}{c}\text { Mar 2017- Nov } \\
2018\end{array}$ & 53 & $\geqslant 17$ years & $\begin{array}{l}\text { MDR-TB: MDR (35), } \\
\text { pre-XDR (1), XDR } \\
\text { (17) }\end{array}$ & $\begin{array}{l}\text { Individualised } \\
\text { regimens with Bdq } \\
+ \text { Dlm }\end{array}$ & $\begin{array}{l}\text { Bdq+Dlm: } 53 \\
\text { Exposure to Mfx }{ }^{\mathrm{Hd}} \text {, } \\
\text { Imp, Lzd and Cfz } \\
\text { cannot be } \\
\text { calculated }\end{array}$ & $\begin{array}{l}32 \% \geqslant 1 \text { SAE } \\
19 \% \text { or } 21 \% \text { died }^{\S}\end{array}$ & $\begin{array}{l}\text { All drugs: } 2 \% \text { due to } \\
\text { cardiac arrhythmia }\end{array}$ & $\begin{array}{l}\text { QTcF> } 60 \mathrm{~ms} \text { above } \mathrm{BL}: \\
14 \% \\
\text { QTcF> } 480 \mathrm{~ms}: 21 \%\end{array}$ \\
\hline
\end{tabular}




\begin{tabular}{|c|c|c|c|c|c|c|c|c|c|c|c|}
\hline $\begin{array}{l}\text { First author } \\
\text { [ref.] }\end{array}$ & Location & Setting & $\begin{array}{l}\text { Patient } \\
\text { enrolment } \\
\text { period }\end{array}$ & Patients n & $\begin{array}{l}\text { Patient age } \\
\text { years }\end{array}$ & Patient type & Drug or regimen & $\begin{array}{l}\text { Patients receiving } \\
\text { ND\&R n }\end{array}$ & Patients with SAE & $\begin{array}{l}\text { Patients with drug(s) } \\
\text { interrupted or } \\
\text { withdrawn }\end{array}$ & $\begin{array}{l}\text { Patients with any } \\
\text { type of } A E\end{array}$ \\
\hline SKRAHINA [66] & Belarus & $\begin{array}{l}\text { aDSM data from } \\
\text { patients receiving } \\
\text { Bdq }\end{array}$ & $\begin{array}{l}\text { June 2015-June } \\
2016 ? \text { (end of } \\
\text { observation NR) }\end{array}$ & 197 & NR & $\begin{array}{l}\text { MDR-TB: MDR (10), } \\
\text { MDR+FQ-R (34), } \\
\text { MDR+SLID-R } \\
\text { (25), XDR (128) }\end{array}$ & $\begin{array}{l}\text { NR (regimens with } \\
\text { Bdq) }\end{array}$ & Bdq: 197 & $\begin{array}{l}\text { NR } \\
\text { "1 death possibly } \\
\text { related to MDR-TB } \\
\text { treatment" }\end{array}$ & NR & $\begin{array}{l}\text { Disorder (most commonly } \\
\text { reported AE): } \\
\text { Metabolism and nutrition: } \\
68 \% \text { (hyperuricaemia) } \\
\text { Hepatobiliary: 64\% } \\
\text { (hepatic functions } \\
\text { abnormality) } \\
\text { Electrolyte: } 47 \% \\
\text { (hypomagnaesemia) } \\
\text { Cardiac: } 41 \% \text { (abnormal } \\
\text { ECG/arrhythmias) } \\
\text { Gl system: } 35 \% \text { (nausea, } \\
\text { vomiting, abdominal } \\
\text { pain) } \\
\text { Blood/lymphatic system: } \\
27 \% \text { (low platelet } \\
\text { counts) } \\
\text { Renal and urinary: } 21 \% \\
\text { (creatinine increased) } \\
\text { Nervous system: } 20 \% \\
\text { (headache, dizziness, } \\
\text { paraesthesia) } \\
\text { Skin and subcutaneous } \\
\text { tissue: } 18 \% \text { (rash, } \\
\text { pruritis) } \\
\text { Ear and labyrinth: } 17 \% \\
\text { (tinnitus, hearing loss) } \\
\text { Psychiatric: } 15 \% \\
\text { (insomnia) } \\
\text { Infections and infestations: } \\
\text { 14\% (candidiasis) }\end{array}$ \\
\hline SKRAHINA [65] & Belarus & $\begin{array}{l}\text { aDSM data for } \\
\text { patients on } \\
\text { regimens with Lzd } \\
\text { and Bdq }\end{array}$ & $\begin{array}{l}\text { Jun 2014-Jun } \\
2016 ? \text { (end of } \\
\text { observation NR) }\end{array}$ & 214 & NR & $\begin{array}{l}\text { MDR-TB (BL } \\
\text { resistance } \\
\text { unknown) }\end{array}$ & $\begin{array}{l}\text { NR; regimens with } \\
\text { Lzd and/or Bdq }\end{array}$ & $\begin{array}{l}\text { Lzd: } 205 \\
\text { Bdq: } 133 \\
\text { (Lzd+Bdq: 124) }\end{array}$ & $\begin{array}{l}\text { Lzd: } 5 \% \text { any SAE req } \\
\text { dosage reduction of } \\
\text { specified } \\
\text { Bdq: } 4 \% \text { any SAE requ } \\
\text { dosage reduction of } \\
\text { Specifiec } \\
\text { \% } \% \text { died due to SAE ca }\end{array}$ & $\begin{array}{l}\text { quiring withdrawal or } \\
\text { f TB medicines (not } \\
d \text { which) } \\
\text { uiring withdrawal or } \\
\text { f TB medicines (not } \\
\text { d which) } \\
\text { aused by Lzd or Bdq }\end{array}$ & $\begin{array}{l}\text { Lzd: any ADR } 78 \% \\
\text { Bdq: any ADR } 72 \%\end{array}$ \\
\hline
\end{tabular}

ND\&R: new drugs and regimens; SAE: serious adverse event; AE: adverse event; MSF: Médecins Sans Frontières; NR: not reported; MDR: multidrug-resistant; TB: tuberculosis; STR: shorter (9-month) treatment regimen; Km: kanamycin; Bdq: bedaquiline; AST: aspartate transaminase; ALT: alanine transaminase; Dlm: delamanid; ERS: European Respiratory Society; WHO: World Health Organization; PiH: Partners in Health; XDR: extensively drug-resistant; Lzd: linezolid; Cfz: clofazimine; QTcF: Fridericia-corrected QT interval; FQ-R: fluoroquinolone resistance; SLID-R: second-line injectable drug resistance; ADR: adverse drug reaction; Lfx: levofloxacin; BL: baseline; Mer: meropenem; PAS: para-aminosalicylic acid; Cm: capreomycin; Cs: cycloserine; Mfx ${ }^{H D}$ : high-dose moxifloxacin (dose not specified in paper); Imp: imipenem; GI: gastrointestinal. ${ }^{\#}$ : only reported for those who completed Dlm treatment of 6 months $(n=66)$; ${ }^{\text {I }}$ only those percentages being different in the group not receiving Bdq are displayed, the proportion of ototoxicity in the Bdq group versus the non-Bdq group is striking because fewer patients in the Bdq group received aminoglycosides/capreomycin than in the non-Bdq group lauthors attributed this difference to the effect of previous treatment and not to the current regimen, it is likely some of the patients in the Bdq group had been given Bdq because of a pre-existing hearing impairment); ${ }^{+}$: out of all AEs (not per patient); ${ }^{\S}$ : conflicting data between table ( $\mathrm{n}=10$ deaths) and text ( $\mathrm{n}=11$ deaths). 
one report describes this for Dlm [68], two reports for two cohorts receiving both Bdq and Dlm [23, 70], and one report describes the safety and efficacy of a modified STR in which kanamycin was replaced with Bdq [67]. The safety data obtained from these reports are summarised in table 1. Most reports focused on QT prolongation. There was a large range in the frequency of any AE, with 38\% [69] to 96\% [18] of the patients reporting at least one AE. A systematic review also concluded that the frequency and type of AEs among RR-/MDR-TB patients reported in the published literature varies greatly across studies [38]. This may in part be due to differences in treatment regimens, patient selection, availability of clinical monitoring tests for early detection of AEs and variable management of AEs. But it probably also illustrates cultural differences, focus on different types of AEs, omissions and mistakes (both in reporting by patients and healthcare workers) and differences in recording. Differential reporting is probably partly owing to the fact that the vast majority of AEs reported by patients are mild and nonspecific, and it is thus left to the clinician's judgement whether or not such an AE should be reported. For example, very low concordance was found between types of AEs reported by clinicians (with associated significant under-recording of AEs by clinicians) as compared to patient's reports in a cross-sectional study of 121 South African DR-TB patients [71]. Increased awareness about AEs and ADRs and why these should be reported may help to improve reporting [72].

Still, there are major constraints in terms of human and financial resources for PV [58], probably because investing in PV systems is considered a luxury in countries where not all those who have health needs even have access to appropriate treatment [56]. Because of the absence of strong PV structures and confusion about PV requirements, some countries have reported that the requirement for active PV has delayed the implementation of ND\&R in their country $[73,74]$.

\section{Country experiences in the introduction of active drug safety monitoring}

Translating global policy into practice, the KNCV, in the framework of the United States Agency for International Development-funded Challenge TB project, prepared a generic implementation guide for the introduction of ND\&R for the treatment of DR-TB [75]. This document provides practical guidance on all aspects that need to be addressed when introducing ND\&R, including the implementation of aDSM, while building on the WHO policy [44]. Challenge TB/KNCV recommend that the countries supported by the project choose the intermediate package of aDSM, if feasible, because the core package is regarded as the bare minimum, while the advanced package is usually not feasible given the limitations in staff and other resources in these countries. Programmes that have adopted the intermediate aDSM package should not forget to stress the importance of early detection and management of AEs that may not be of special interest, because these may affect the patients' quality of life and jeopardise treatment outcomes. Healthcare providers should take the opportunity to report previously unknown AEs to increase knowledge about the safety profiles of ND\&R.

Because KNCV sees a central role for the national PV authorities if available in the country [75], we actively involved the NPVCs from the first phase of preparing the country for the introduction of aDSM to avoid duplication of work and to build a sustainable system. This is in line with recommendations by PV experts for a central role of the national PV authorities in all PV-related activities; these experts stress that the PV authorities should decide which products are approved for use in public health programmes and advise them to make the reporting of $\mathrm{AE}$ and medication errors mandatory for all organisations acting as "marketing authorisation holders" (note that these can be public health programmes for unregistered products that enter the country through special access arrangements, which is often the case for Bdq, Dlm and repurposed drugs) [56].

Here, we present data from a representative set of countries that were implementing aDSM and collecting data in 2017 in which we assisted in organising active PV for ND\&R (table 2). While NPVCs were available in all six of these example countries, until the introduction of aDSM for ND\&R they had mainly, or only, conducted spontaneous reporting, with the exception of Vietnam. The overall number of spontaneous reports received per year was low in most countries (1.1 in Myanmar (2015) to 24 in Kyrgyzstan (2014) per million population). An exception was Vietnam, where the PV centre received 108 reports per million population in 2015. The number of reports specifically concerning TB treatment was low in most countries. In Kyrgyzstan, 46 (33\%) of the reported AEs were related to drugs used for the treatment of $\mathrm{TB}$, while the Indonesian PV centre received 355 AE reports ( $16 \%$ of the total number of reports received) related to anti-TB drugs in 2014, 54 of which were submitted by the NTP. In Myanmar, there were no AE reports about patients receiving TB treatment before the introduction of aDSM. This indicates that, although treating physicians are generally aware of the occurrence of (well-known) ADRs during TB treatment, there is little awareness of the usefulness of reporting AEs in general, whether new, previously unknown ADRs or clinically well-known but rare reactions of frequently used drugs not yet described in the summaries of product characteristics. 
TABLE 2 Organisation of active pharmacovigilance (PV) for new drugs and regimens in programmatic settings

\begin{tabular}{|c|c|c|c|c|c|c|}
\hline Country & $\begin{array}{l}\text { Type of PV/aDSM } \\
\text { package (time frame) } \\
\text { Type of TB patient } \\
\text { (number of sites) }\end{array}$ & $\begin{array}{l}\text { Type of forms and } \\
\text { reporting lines }\end{array}$ & Report assessment & CA & Strengths & Challenges \\
\hline Ethiopia & $\begin{array}{l}\text { aDSM intermediate } \\
\text { package (April } \\
\text { 2017) } \\
\text { All DR-TB patients } \\
\text { starting NDs" (3) }\end{array}$ & $\begin{array}{l}\text { NDs: SAE on GDF forms } \\
\text { TICs } \rightarrow \text { NPVC and NTP; } \\
\text { NTP } \rightarrow \text { GDF (within } 24 \text { h) } \\
\text { STR and repurposed drugs: } \\
\text { yellow form land } \\
\text { Excel-based form) } \\
\text { TICs } \rightarrow \text { NPVC and NTP } \\
\text { (monthly) }\end{array}$ & $\begin{array}{l}\text { Reporting overseen by Medical } \\
\text { Officers at TICs } \\
\text { SAE reports reviewed by experts } \\
\text { on the CRC at the central } \\
\text { level }\end{array}$ & $\begin{array}{l}\text { Treating physician/team at } \\
\text { respective TIC and } \\
\text { reported to NPVC and } \\
\text { NTP }\end{array}$ & $\begin{array}{l}\text { National aDSM advisory group in place } \\
\text { Active discussion between NTP, NPVC } \\
\text { and technical partners (especially } \\
\text { CTB and PiH (endTB project)) } \\
\text { Programmatic aDSM implementation } \\
\text { plan developed } \\
\text { SAE reports reviewed by CRC } \\
\text { Both electronic and paper aDSM } \\
\text { reporting forms available at TICs }\end{array}$ & $\begin{array}{l}\text { Poor internet access at most TICs hinders } \\
\text { reporting of SAE within 24-h period } \\
\text { National aDSM advisory group not regularly } \\
\text { involved in aDSM activity planning } \\
\text { No sub-national aDSM advisory groups } \\
\text { Limited staff and lack of capacity for CA at } \\
\text { NPVC } \\
\text { Complex reporting requirements lead to } \\
\text { duplication of work (national, } \\
\text { international (GDF, UMC), programmatic, } \\
\text { project-based (endTB Project)) } \\
\text { Weak linkage between CRC's clinical } \\
\text { management decisions and CA }\end{array}$ \\
\hline Kyrgyzstan & $\begin{array}{l}\text { aDSM intermediate } \\
\text { package ( Jan 2017) } \\
\text { All TB patients (all) }\end{array}$ & $\begin{array}{l}\text { Yellow forms (paper) } \\
\text { TIC } \rightarrow \text { PV staff at NTP } \rightarrow \\
\text { DDP }\end{array}$ & $\begin{array}{l}1 \text { PV staff at NTP oversees PV } \\
\text { data collection, assisted by } 1 \\
\text { PV staff from KNCV (CTB) } \\
\text { 3 PV staff from DDP review } \\
\text { reports }\end{array}$ & $\begin{array}{l}3 \text { PV staff from DDP } \\
\text { assess events with } \\
\text { experts from different } \\
\text { disciplines }\end{array}$ & $\begin{array}{l}\text { PV section at DDP has knowledgeable } \\
\text { staff } \\
\text { Good collaboration between DDP, NTP } \\
\text { and KNCV/CTB } \\
\text { Key staff at TB centres, DDP, MoH and } \\
\text { clinical pharmacologists from the } \\
\text { medical educational facilities trained } \\
\text { on PV }\end{array}$ & $\begin{array}{l}\text { Lack of staff in DDP and no PV officers at } \\
\text { Oblast level, leading to: } \\
\text { - no systematic CA } \\
\text { - no regular feedback from DDP to the } \\
\text { reporters of AE } \\
\text { Additional workload on DR-TB coordinators } \\
\text { and drug supply managers } \\
\text { KNCV staff currently reports SAEs (for Bdq- } \\
\text { and/or Dlm-containing regimens) to GDF }\end{array}$ \\
\hline Tajikistan & $\begin{array}{l}\text { aDSM intermediate } \\
\text { package (December } \\
\text { 2016) } \\
\text { All MDR-TB patients } \\
\text { (7) }\end{array}$ & $\begin{array}{l}\text { Special aDSM page in patient } \\
\text { file } \\
\text { Data transferred from } \\
\text { patient file to customised } \\
\text { database by KNCV/CTB }\end{array}$ & $\begin{array}{l}\text { Reports assessed by PV/PMDT } \\
\text { focal persons of KNCV/CTB } \\
\text { National Thematic Working } \\
\text { Group assesses reports }\end{array}$ & $\begin{array}{l}\text { CA subgroup under the } \\
\text { National Thematic } \\
\text { Working Group on } \\
\text { aDSM }\end{array}$ & $\begin{array}{l}\text { Private laboratory contracted with } \\
\text { funding of CTB ensures timely } \\
\text { high-quality monitoring tests with } \\
\text { sample transportation } \\
\text { Intensive regular monitoring and } \\
\text { supervision have improved recording } \\
\text { and reporting in pilot sites, including } \\
\text { of AEs }\end{array}$ & $\begin{array}{l}\text { Little capacity at PV centre } \\
\text { CA done by the treating clinicians only } \\
\text { Reports not submitted to UMC } \\
\text { System ensuring timely and high-quality } \\
\text { monitoring tests paid by CTB } \\
\text { KNCV staff reports SAEs (for Bdq- and/or } \\
\text { Dlm-containing regimens) to GDF }\end{array}$ \\
\hline Indonesia & $\begin{array}{l}\text { Active } \mathrm{PV}^{+} \\
\text {(Recruitment Aug } \\
\text { 2015-Oct 2017) } \\
\text { All patients on Bdq (5) } \\
\text { aDSM core package } \\
\text { (Oct 2017) } \\
\text { DR-TB patients on } \\
\text { ND\&R (all) }\end{array}$ & $\begin{array}{l}\text { CEM: special form } \\
\text { PV officer on-site } \rightarrow \text { NTPf } \\
1 \text { PV staff at NTP assisted } \\
\text { by KNCV/CTB oversees } \\
\text { data collection } \\
\text { aDSM: paper form (based } \\
\text { on yellow form) } \rightarrow \text { NTP } \\
\text { and NPVC within } 24 \mathrm{~h}\end{array}$ & $\begin{array}{l}\text { PV focal person of NTP with } \\
\text { KNCV/CTB PMDT focal } \\
\text { person retrospectively assess } \\
\text { reports }\end{array}$ & $\begin{array}{l}\text { NPVC and NTP conduct } \\
\text { irregular CA meetings }\end{array}$ & $\begin{array}{l}\text { PV focal person at NTP } \\
1 \text { PV officer available in each pilot site } \\
\text { implementing CEM for Bdq and } 1 \text { PV } \\
\text { focal person at the NTP } \\
\text { Direct links set up between NTP and } \\
\text { NPVC }\end{array}$ & $\begin{array}{l}\text { Assessment of AEs by clinical expert teams } \\
\text { not systematically done } \\
\text { Late CA (NPVC understaffed) Frequent staff } \\
\text { changes, not all sites had a PV officer at } \\
\text { all times of data collection } \\
\text { No PV officers for sites that have no CEM } \\
\text { cohort } \\
\text { aDSM core package not well implemented }\end{array}$ \\
\hline Myanmar & $\begin{array}{l}\text { aDSM core package } \\
\text { (Aug 2017) } \\
\text { DR-TB patients on } \\
\text { ND\&R and } \\
\text { repurposed } \\
\text { drugs (2) }\end{array}$ & $\begin{array}{l}\text { PMDT sites (within } 24 \mathrm{~h} \text { ) } \rightarrow \\
\text { NTP aDSM focal point } \rightarrow \\
\text { NCCA and national PV } \\
\text { database (within } 72 \mathrm{~h} \text { ) } \rightarrow \\
\text { WHO aDSM database } \\
\text { (within } 30 \text { days of SAE } \\
\text { detection) }\end{array}$ & aDSM focal person of NTP & $\begin{array}{l}\text { Clinical professors } \\
\text { through the NCCA } \\
\text { (within } 15 \text { days of SAE } \\
\text { detection) }\end{array}$ & $\begin{array}{l}\text { Clinical professors collaborate closely } \\
\text { with NTP, and lead CA } \\
\text { Feedback on CA to NTP within } 15 \text { days } \\
\text { after reporting } \\
\text { Working on application of membership to } \\
\text { WHO Programme for International } \\
\text { Drug Monitoring assisted by NTP and } \\
\text { partners }\end{array}$ & $\begin{array}{l}\text { Lack of HR in NPVC } \\
\text { Multiple tasks assigned to the NTP aDSM } \\
\text { focal point } \\
\text { Need for upgraded equipment, calibration } \\
\text { and maintenance in facilities for clinical } \\
\text { monitoring }\end{array}$ \\
\hline
\end{tabular}




\begin{tabular}{|c|c|c|c|c|c|c|}
\hline Country & $\begin{array}{c}\text { Type of PV/aDSM } \\
\text { package (time frame) } \\
\text { Type of TB patient } \\
\text { (number of sites) }\end{array}$ & $\begin{array}{l}\text { Type of forms and } \\
\text { reporting lines }\end{array}$ & Report assessment & CA & Strengths & Challenges \\
\hline Vietnam & $\begin{array}{l}\text { aDSM intermediate } \\
\text { package (2018) } \\
\text { DR-TB patients on STR } \\
\text { (all) } \\
\text { CEM pilot (2011-2015) } \\
\text { MDR-TB patients (9) } \\
\text { and patients on } \\
\text { Bdq (3) }\end{array}$ & $\begin{array}{l}\text { PMDT sites } \rightarrow \text { NPVC } \rightarrow \\
\text { national PV database } \\
\text { (Excel sheet) } \rightarrow \text { WHO } \\
\text { global aDSM database } \\
\text { and (specific AEs of } \\
\text { interest) ADR reports to } \\
\text { VigiBase } \circledast \text { of UMC }\end{array}$ & NPVC staff & $\begin{array}{l}\text { NPVC with National } \\
\text { Advisory Committee } \\
\text { (professors, } \\
\text { pharmacists) }\end{array}$ & $\begin{array}{l}\text { Strong collaboration between the NTP } \\
\text { and NPVC } \\
\text { Reports can be filled in directly on } \\
\text { computer via modifiable PDF and sent } \\
\text { to NPVC by e-mail } \\
\text { NPVC has a network of clinical experts } \\
\text { that can be consulted during CA }\end{array}$ & $\begin{array}{l}\text { High workload of NPVC staff } \\
\text { Active PV has further increased } \\
\text { administrative burden of clinicians, } \\
\text { leading to late reporting and incomplete/ } \\
\text { low quality reports } \\
\text { Different forms of active PV (first CEM, now } \\
\text { aDSM) initially led to confusion with } \\
\text { clinicians and underreporting for aDSM } \\
\text { Low capacity of DR-TB clinicians to measure } \\
\text { and interpret ECGs and audiometry } \\
\text { reports }\end{array}$ \\
\hline
\end{tabular}

aDSM: active drug safety management and monitoring; CA: causality assessment; DR: drug-resistant; TB: tuberculosis; ND: new drugs; SAE: serious adverse event; GDF: Global Drug Facility; TIC: treatment initiation site (Ethiopia); NPVC: national PV centre; NTP: national TB programme; STR: shorter treatment regimen (for certain eligible forms of DR-TB); CRC: clinical review committee; CTB: Challenge TB (Flagship TB project of USAID); PiH: Partners in Health (NGO); UMC: Uppsala Monitoring Centre (Collaborating Centre of the WHO for PV); DDP: Department of Drug Procurement lof Kyrgyzstan); MoH: Ministry of Health; AE: adverse event; Bdq: bedaquiline; Dlm: delamanid; MDR: multidrug-resistant; PMDT: programmatic management of DR-TB; ND\&R: new drugs and regimens; CEM: cohort event monitoring; HR: human resources; NCCA: National Core Committee for aDSM; WHO: World Health Organization; ADR: adverse drug reaction. " : active monitoring done at one of the sites from late August 2016 under the Unitaid-supported EndTB project; ": eight sites now can use new drugs, with the shorter treatment regimen being introduced in all PMDT treatment sites from April 2018; ${ }^{+}$: the project started as a CEM project, but because not all PV officers were retained, or able to collect information on all AEs occurring, for four of the five sites in practice CEM became the aDSM intermediate package; ${ }^{\S}$ : as of May 2019 , this is not yet fully implemented; ${ }^{f}$ : originally done through e-TB Manager, but because that did not work well, later data were collected retrospectively from paper forms and added to a Microsoft Excel file. 
To introduce active PV in these countries, KNCV organised several joint training sessions for clinical staff and staff from the PV unit to bolster understanding of PV and related processes, particularly on the detection, clinical management and reporting of AEs and on causality assessment. Key activities further included the formation of a technical working group on PV representing all key stakeholders, which should facilitate collaboration between the NTP and the NPVC in conducting active PV; developing a national guidance document on the introduction of ND\&R, including the detection, clinical management and reporting of AEs with a roadmap for scale-up; organising access to monitoring tests required for the safe introduction of ND\&R; developing a specific (aDSM) reporting form for AEs; and setting up the AE report flow from facility level to national and global levels. The implementation process was strengthened by on-the-job training of staff involved, including supportive supervision visits and (distance) mentoring.

Four of the countries chose to adopt the aDSM intermediate package; because of limited human resources, in Myanmar the core aDSM package was adopted (table 2). Indonesia initially selected CEM, because at that time, the WHO aDSM guidance document [44] was not yet available. A PV officer with a medical doctor's or pharmacist's degree was hired for each of the three pilot centres implementing the ND\&R to facilitate the NTP's efforts to systematically collect and record safety data using Global Fund resources. The main issues with the implementation of CEM were the workload; the high turnover of PV officers; confusion over the responsibilities of the NTP and the NPVC (e.g. who should initiate the causality assessment?); and limitations in human resource capacity, causing considerable delays in the conduct of causality assessment. Because of these challenges, the programme decided to shift to the core aDSM package for further scaling-up the aDSM.

In all countries, there were limited human resources for PV and frequent personnel changes, which affected the level of expertise in the validation of reports, causality assessment and signal detection. As a consequence, receipt of $\mathrm{AE}$ reports was not always acknowledged, reports were not regularly checked and causality assessment was delayed. Most countries were necessarily focusing on assessing the SAEs first, while assessment of the AEs of special interest was postponed. Because feedback on their reports, including the results of causality assessment, was often not sent to the reporters, clinicians were not motivated to send in new reports. The commonly weak link between the NPVCs and the NTPs hindered data and result sharing and lowered the motivation of NTPs to strengthen AE reporting. Clinicians were often over-burdened with their clinical duties and administrative tasks, and having to report AEs further increased their workload.

There was also lack of clarity about which authority (the NPVC or the NTP) holds the final responsibility for the active PV programme. This has led to problems in the organisation of causality assessment meetings in some countries. Currently, active PV is often limited to specific sites piloting the ND\&R. However, further scaling-up of aDSM to cover all DR-TB patients on treatment is needed to ensure that their safety is sufficiently monitored.

In countries where aDSM is functioning relatively well (such as Vietnam and Kyrgyzstan), the NTP and the NPVC have managed to establish a strong collaboration, organising regular meetings and joint causality assessment exercises. aDSM is, hence, mutually owned and responsibilities are shared.

Table 3 shows an overview of the number of patients enrolled in aDSM and the number of reports received. There were AE data available for 477 patients on longer regimens with Bdq from six countries; for 100 patients on longer regimens with Dlm from three countries; for eight patients on longer regimens with Bdq and Dlm from Myanmar only; for 263 patients on STR from three countries; and for 265 patients on the standard longer DR-TB regimen from Vietnam only. The average number of AEs and SAEs reported per patient was higher for Bdq-containing regimens then for the other regimens, but this was distorted at least in part by different levels of active PV being applied (e.g. CEM in Vietnam). Ethiopia, Kyrgyzstan and Myanmar were the only countries from which data from patients on Bdq-containing and Dlm-containing regimens could be compared; there was no consistent pattern of higher frequency of AEs for patients on Bdq. Kyrgyzstan and Myanmar also provided a comparison between STR and the longer regimens, and the number of AEs per patient was lower for STR patients than for patients on longer regimens (with Bdq and/or Dlm).

\section{Key lessons from example countries}

The introduction of active PV/aDSM has faced many challenges because the NTPs and the PV authorities had limited awareness of aDSM or active PV for ND\&R. Consultation and raising awareness helped to open an active dialogue between the NTP and the NPVC so that they could gain a common understanding of the issues and jointly plan the way forward.

Our experience showed that it worked best to build on a country's existing PV system, which in some settings meant revitalising the existing dormant one. A significant amount of capacity building on 


\begin{tabular}{|c|c|c|c|c|c|c|}
\hline Country & Regimen type & Reporting period & $\begin{array}{l}\text { Patients started on } \\
\text { active PV monitoring } n\end{array}$ & $\begin{array}{l}\text { AEs lincludes } \\
\text { SAE) } n\end{array}$ & $\begin{array}{l}\text { SAEs }^{\#} \text { (includes } \\
\text { death) } n\end{array}$ & Deaths $^{\pi} n$ \\
\hline \multirow[t]{3}{*}{ Ethiopia } & Individualised+Bdq & Mar-Dec $2017^{+}$ & 16 & 15 & 4 & 2 \\
\hline & Individualised+Dlm & Mar-Dec $2017^{+}$ & 7 & 12 & 2 & 0 \\
\hline & Shorter treatment regimen & Mar-Dec $2017^{+}$ & 0 & NA & NA & NA \\
\hline \multirow[t]{4}{*}{ Kyrgyzstan } & Individualised+Bdq & Jan-Dec 2017 & 133 & 23 & 8 & 5 \\
\hline & Individualised+Dlm & Jan-Dec 2017 & 79 & 6 & 0 & 0 \\
\hline & Shorter treatment regimen & Jan-Dec 2017 & 129 & 4 & 0 & 0 \\
\hline & Standard DS- and DR-TB regimens & Jan-Dec 2017 & Exact number unknown & 81 & 0 & 0 \\
\hline \multirow[t]{2}{*}{ Tajikistan } & Individualised $+B d q$ & Dec 2016-Dec 2017 & 64 & 13 & 5 & 3 \\
\hline & Shorter treatment regimen & Dec 2016-Dec 2017 & 75 & 8 & 0 & 0 \\
\hline Indonesia & Individualised+Bdq & Sept 2015-Apr 2018 & 120 & 285 & 77 & 13 \\
\hline \multirow[t]{4}{*}{ Myanmar } & Individualised+Bdq & Jul 2017-Mar 2018 & 45 & 5 & 5 & 2 \\
\hline & Individualised+Dlm & Jul 2017-Mar 2018 & 14 & 5 & 5 & 1 \\
\hline & Individualised+Bdq and DIm & Jul 2017-Mar 2018 & 8 & 2 & 2 & 0 \\
\hline & Shorter treatment regimen & Nov 2017-Mar 2018 & 59 & 9 & 9 & 0 \\
\hline \multirow[t]{2}{*}{ Vietnam } & Individualised $+\mathrm{Bdq}^{\S}$ & Nov 2015- Dec 2017 & 99 & $758^{\# \#}$ & $65^{\# \#, 917}$ & 7 \\
\hline & Standard DR-TB regimens ${ }^{f}$ & Oct 2017-Oct 2018 & 265 & 40 & 21 & 1 \\
\hline \multicolumn{7}{|c|}{ 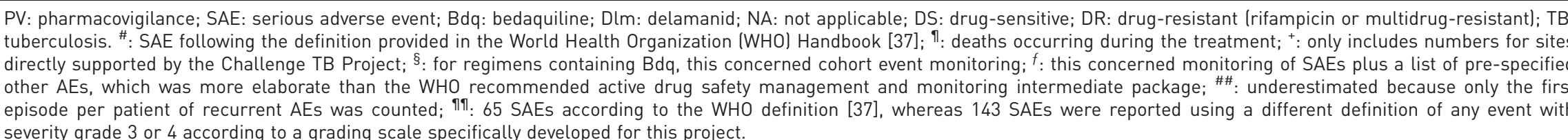 } \\
\hline
\end{tabular}


PV/aDSM at all levels of the health system was required in most countries. High staff turnover threatens the expertise and capacities built, underlining the importance of continuous training, including on-the-job and step-down mentoring, in order to create a large and sustainable pool of staff with sufficient knowledge on aDSM.

Most healthcare providers indicated that they would appreciate receiving regular feedback on their reports that goes beyond an acknowledgement of receipt. Although funding and capacity are usually lacking to send individual feedback reports, there are good examples of regular newsletters sharing updates from the PV centre, such as the MESO newsletter in Indonesia that includes an overview of PV reports received in the past period (by reporter, type of $\mathrm{AE}$ and drug class) and newly detected signals (http://e-meso.pom.go. $\mathrm{id} /$ web/index.php?act=bulletinmeso\&lang=1\&action=\&eventId=38\&newsId=).

Because there is usually very limited funding for PV activities both in public health programmes and for NPVC/drug regulatory authorities, partner support is still required to set up active PV systems and strengthen collaborating mechanisms.

Global reporting of aDSM data is being promoted. However, the current existence of at least four different global database initiatives may result in the collection of fragmented data, without yielding a clear overall picture of the frequency and types of AEs among patients on ND\&R.

\section{Conclusions}

The introduction of ND\&R for the treatment of (DR-)TB has come with the requirement and new standard of conducting active PV in parallel. The 2015 WHO guidance for aDSM for DR-TB treatment programmes triggered the introduction of active PV in many low- and middle-income countries, assisted by support from international partners such as the Union, Médecins Sans Frontières and KNCV. Because the existing capacity for PV is limited in most of these countries (both within the NTP and the NPVC), there needs to be systematic and collaborative development of capacities on both sides. Such collaboration will also help to increase NPVC staff knowledge about DR-TB and its treatment. First experiences with active PV for TB patients shows that the number of PV reports sent to NPVCs has increased. We expect that establishing the practice of aDSM will ultimately result in the earlier detection and better management of AEs and, thus, better treatment outcomes. It may also contribute to the establishment of more complete drug safety profiles. To achieve this, stronger national and international commitment to building and maintaining well-equipped national and sub-national PV centres with well-trained staff will be required.

Support statement: The Global Health Bureau, Office of Infectious Disease, US Agency for International Development (USAID), financially supported this publication through Challenge TB under the terms of Agreement No. AID-OAA-A-14-00029. This publication is made possible by the generous support of the American people through the USAID. The contents are the responsibility of Challenge TB and do not necessarily reflect the views of USAID or the US Government. Funding information for this article has been deposited with the Crossref Funder Registry.

Conflict of interest: E. Tiemersma reports grants from USAID under the Challenge TB Project, during the conduct of the study. S. van den Hof has nothing to disclose. G. Dravniece has nothing to disclose. F. Wares reports grants from USAID under the Challenge TB Project, during the conduct of the study. Y. Molla reports grants from the USAID under the Challenge TB Project, during the conduct of the study. Y. Permata has nothing to disclose. E. Lukitosari has nothing to disclose. M. Quelapio has nothing to disclose. S.T. Aung has nothing to disclose. K.M. Aung has nothing to disclose. H.T. Thuy has nothing to disclose. V.D. Hoa has nothing to disclose. M. Sulaimanova has nothing to disclose. S. Sagyndykova has nothing to disclose. M. Makhmudova has nothing to disclose. A. Soliev has nothing to disclose. M. Kimerling has nothing to disclose.

\section{References}

1 Aung KJ, Van Deun A, Declercq E, et al. Successful '9-month Bangladesh regimen' for multidrug-resistant tuberculosis among over 500 consecutive patients. Int J Tuberc Lung Dis 2014; 18: 1180-1187.

2 Van Deun A, Maug AK, Salim MA, et al. Short, highly effective, and inexpensive standardized treatment of multidrug-resistant tuberculosis. Am J Respir Crit Care Med 2010; 182: 684-692.

3 Kuaban C, Noeske J, Rieder HL, et al. High effectiveness of a 12-month regimen for MDR-TB patients in Cameroon. Int J Tuberc Lung Dis 2015; 19: 517-524.

4 Piubello A, Harouna SH, Souleymane MB, et al. High cure rate with standardised short-course multidrug-resistant tuberculosis treatment in Niger: no relapses. Int J Tuberc Lung Dis 2014; 18: 1188-1194.

5 Ahmad Khan F, Salim MAH, du Cros P, et al. Effectiveness and safety of standardised shorter regimens for multidrugresistant tuberculosis: individual patient data and aggregate data meta-analyses. Eur Respir J 2017; 50: 1700061.

6 Diacon AH, Pym A, Grobusch MP, et al. Multidrug-resistant tuberculosis and culture conversion with bedaquiline. $N$ Engl J Med 2014; 371: 723-732.

7 World Health Organization. The Use of Bedaquiline in the Treatment of Multidrug-resistant Tuberculosis. Interim Policy Guidance. Geneva, World Health Organization, 2013.

8 Skripconoka V, Danilovits M, Pehme L, et al. Delamanid improves outcomes and reduces mortality in multidrug-resistant tuberculosis. Eur Respir J 2013; 41: 1393-1400. 
9 World Health Organization. The Use of Delamanid in the Treatment of Multidrug-resistant Tuberculosis. Interim Policy Guidance. Geneva, World Health Organization, 2014.

10 Pym AS, Diacon AH, Tang SJ, et al. Bedaquiline in the treatment of multidrug- and extensively drug-resistant tuberculosis. Eur Respir J 2016; 47: 564-574.

11 Borisov SE, Dheda K, Enwerem M, et al. Effectiveness and safety of bedaquiline-containing regimens in the treatment of MDR- and XDR-TB: a multicentre study. Eur Respir J 2017; 49: 1700387.

12 Guglielmetti L, Jaspard M, Le Dû D, et al. Long-term outcome and safety of prolonged bedaquiline treatment for multidrug-resistant tuberculosis. Eur Respir J 2017; 49: 1601799.

13 Guglielmetti L, Le Dû D, Jachym M, et al. Compassionate use of bedaquiline for the treatment of multidrugresistant and extensively drug-resistant tuberculosis: interim analysis of a French cohort. Clin Infect Dis 2015; 60: 188-194.

14 Ndjeka N, Conradie F, Schnippel K, et al. Treatment of drug-resistant tuberculosis with bedaquiline in a high HIV prevalence setting: an interim cohort analysis. Int J Tuberc Lung Dis 2015; 19: 979-985.

15 Ferlazzo G, Mohr E, Laxmeshwar C, et al. Early safety and efficacy of the combination of bedaquiline and delamanid for the treatment of patients with drug-resistant tuberculosis in Armenia, India, and South Africa: a retrospective cohort study. Lancet Infect Dis 2018; 18: 536-544.

16 Hewison C, Bastard M, Khachatryan N, et al. Is 6 months of bedaquiline enough? Results from the compassionate use of bedaquiline in Armenia and Georgia. Int J Tuberc Lung Dis 2018; 22: 766-772.

17 Ndjeka N, Schnippel K, Master I, et al. High treatment success rate for multidrug-resistant and extensively drug-resistant tuberculosis using a bedaquiline-containing treatment regimen. Eur Respir J 2018; 52: 1801528.

18 Olayanju O, Limberis J, Esmail A, et al. Long-term bedaquiline-related treatment outcomes in patients with extensively drug-resistant tuberculosis from South Africa. Eur Respir J 2018; 51: 1800544.

19 Udwadia ZF, Ganatra S, Mullerpattan JB. Compassionate use of bedaquiline in highly drug-resistant tuberculosis patients in Mumbai, India. Eur Respir J 2017; 49: 1601699.

20 Tsuyuguchi K, Sasaki Y, Mitarai S, et al. Safety, efficacy, and pharmacokinetics of bedaquiline in Japanese patients with pulmonary multidrug-resistant tuberculosis: an interim analysis of an open-label, phase 2 study. Respir Investig 2019; 57: 345-353.

21 Achar J, Hewison C, Cavalheiro AP, et al. Off-label use of bedaquiline in children and adolescents with multidrug-resistant tuberculosis. Emerg Infect Dis 2017; 23: 1711-1713.

22 Guglielmetti L, Barkane L, Le Dû D, et al. Safety and efficacy of exposure to bedaquiline-delamanid in multidrug-resistant tuberculosis: a case series from France and Latvia. Eur Respir J 2018; 51: 1702550.

23 Hafkin J, Hittel N, Martin A, et al. Compassionate use of delamanid in combination with bedaquiline for the treatment of multidrug-resistant tuberculosis. Eur Respir J 2019; 53: 1801154.

24 Pontali E, Sotgiu G, Tiberi S, et al. Cardiac safety of bedaquiline: a systematic and critical analysis of the evidence. Eur Respir J 2017; 50: 1701462.

25 Von Groote-Bidlingmaier F, Patientia R, Sanchez E, et al. Efficacy and safety of delamanid in combination with an optimised background regimen for treatment of multidrug-resistant tuberculosis: a multicentre, randomised, double-blind, placebo-controlled, parallel group phase 3 trial. Lancet Respir Med 2019; 7: 249-259.

26 Zhang Q, Liu Y, Tang S, et al. Clinical benefit of delamanid (OPC-67683) in the treatment of multidrug-resistant tuberculosis patients in China. Cell Biochem Biophys 2013; 67: 957-963.

27 World Health Organization. WHO Position Statement on the Use of Delamanid for Multi-Drug Resistant Tuberculosis. Expedited Review of the Phase III Clinical Trial Data of Delamanid Added to an Optimised Background MDR-TB Regimen. Geneva, World Health Organization, 2018.

28 Hewison C, Ferlazzo G, Avaliani Z, et al. Six-month response to delamanid treatment in MDR TB patients. Emerg Infect Dis 2017; 23: 1746-1758.

29 Kuksa L, Barkane L, Hittel N, et al. Final treatment outcomes of multidrug- and extensively drug-resistant tuberculosis patients in Latvia receiving delamanid-containing regimens. Eur Respir J 2017; 50: 1701105.

30 Mohr E, Hughes J, Reuter A, et al. Delamanid for rifampicin-resistant tuberculosis: a retrospective study from South Africa. Eur Respir J 2018; 51: 1800017.

31 Mok J, Kang H, Hwang SH, et al. Interim outcomes of delamanid for the treatment of MDR- and XDR-TB in South Korea. J Antimicrob Chemother 2018; 73: 503-508.

32 Mafukidze A, Harausz E, Furin J. An update on repurposed medications for the treatment of drug-resistant tuberculosis. Expert Rev Clin Pharmacol 2016; 9: 1331-1340.

33 Nunn AJ, Phillips PPJ, Meredith SK, et al. A trial of a shorter regimen for rifampin-resistant tuberculosis. $N$ Engl J Med 2019; 380: 1201-1213.

34 Zhang X, Falagas ME, Vardakas KZ, et al. Systematic review and meta-analysis of the efficacy and safety of therapy with linezolid containing regimens in the treatment of multidrug-resistant and extensively drug-resistant tuberculosis. J Thorac Dis 2015; 7: 603-615.

35 Singh B, Cocker D, Ryan H, et al. Linezolid for drug-resistant pulmonary tuberculosis. Cochrane Database Syst Rev 2019; 3: CD012836.

36 World Health Organization. The Importance of Pharmacovigilance - Safety Monitoring of Medicinal Products. Geneva, World Health Organization, 2002.

37 World Health Organization. A Practical Handbook on the Pharmacovigilance of Medicines Use in the Treatment of Tuberculosis. Geneva, World Health Organization, 2012

38 Wu S, Zhang Y, Sun F, et al. Adverse events associated with the treatment of multidrug-resistant tuberculosis: a systematic review and meta-analysis. Am J Ther 2016; 23: e521-e530.

39 Schnippel K, Firnhaber C, Berhanu R, et al. Adverse drug reactions during drug-resistant TB treatment in high HIV prevalence settings: a systematic review and meta-analysis. J Antimicrob Chemother 2017; 72: 1871-1879.

40 Bloss E, Kuksa L, Holtz TH, et al. Adverse events related to multidrug-resistant tuberculosis treatment, Latvia, 2000-2004. Int J Tuberc Lung Dis 2010; 14: 275-281.

41 Akshata JS, Chakrabarthy A, Swapna R, et al. Adverse drug reactions in management of multi drug resistant tuberculosis, in tertiary chest institute. J Tuberc Res 2015; 3: 27-33.

42 Keshavjee S, Gelmanova IY, Farmer PE, et al. Treatment of extensively drug-resistant tuberculosis in Tomsk, Russia: a retrospective cohort study. Lancet 2008; 372: 1403-1409. 
43 Strengthening Pharmaceutical Systems (SPS) Program. Safety of Medicines in Sub-Saharan Africa: Assessment of Pharmacovigilance Systems and their Performance. Submitted to the US Agency for International Development by the SPS Program. Arlington, VA, Management Sciences for Health, 2011.

44 World Health Organization. Active TB Drug-Safety Monitoring and Management (aDSM). Framework for Implementation. WHO/HTM/TB/2015.28. Geneva, World Health Organization, 2015.

45 World Health Organization. Guidelines for the Programmatic Management of Drug-Resistant Tuberculosis. WHO/HTM/TB/2006.361. Geneva, World Health Organization, 2006.

46 Maher D, Raviglione MC. Why is a recording and reporting system needed, and what system is recommended? In: Frieden TR, ed. Toman's Tuberculosis. 2nd Edn. Geneva, World Health Organization, 2004; pp. $270-273$.

47 TBCARE-1. International Standards For Tuberculosis Care. 3rd Edn. The Hague, TBCARE-1, 2014.

48 World Health Organization. Companion Handbook to the WHO Guidelines for the Programmatic Management of Drug-Resistant Tuberculosis. WHO/HTM/TB/2014.11. Geneva, World Health Organization, 2014.

49 Pal SN, Duncombe C, Falzon D, et al. WHO strategy for collecting safety data in public health programmes: complementing spontaneous reporting systems. Drug Saf 2013; 36: 75-81.

50 Tadolini M, Garcia-Prats AJ, D'Ambrosio L, et al. Compassionate use of new drugs in children and adolescents with multidrug-resistant and extensively drug-resistant tuberculosis: early experiences and challenges. Eur Respir $J$ 2016; 48: 938-943.

51 McIlleron H, Abdel-Rahman S, Dave JA, et al. Special populations and pharmacogenetic issues in tuberculosis drug development and clinical research. J Infect Dis 2015; 211: Suppl. 3, S115-S125.

52 World Health Organization. Global Tuberculosis Report 2018. WHO/CDS/TB/2018.20. Geneva, World Health Organization, 2018

53 Singh A, Bhatt P. Comparative evaluation of adverse drug reaction reporting forms for introduction of a spontaneous generic ADR form. J Pharmacol Pharmacother 2012; 3: 228-232.

54 Hazell L, Shakir SA. Under-reporting of adverse drug reactions: a systematic review. Drug Saf 2006; 29: $385-396$.

55 Ampadu HH, Hoekman J, de Bruin ML, et al. Adverse drug reaction reporting in Africa and a comparison of individual case safety report characteristics between Africa and the rest of the world: analyses of spontaneous reports in VigiBase ${ }^{\circledR}$. Drug Saf 2016; 39: 335-345.

56 Olsson S, Pal SN, Dodoo A. Pharmacovigilance in resource-limited countries. Expert Rev Clin Pharmacol 2015; 8 . 449-460.

57 Systems for Improved Access to Pharmaceuticals and Services (SIAPS) Program. Comparative Analysis of Pharmacovigilance Systems in Five Asian Countries. Submitted to the US Agency for International Development by SIAPS. Arlington, VA, Management Sciences for Health, 2013.

58 Ampadu HH, Hoekman J, Arhinful D, et al. Organizational capacities of national pharmacovigilance centres in Africa: assessment of resource elements associated with successful and unsuccessful pharmacovigilance experiences. Global Health 2018; 14: 109.

59 Sagwa EL, Souverein PC, Ribeiro I, et al. Differences in VigiBase reporting of aminoglycoside and capreomycin-suspected ototoxicity during tuberculosis treatment. Pharmacoepidemiol Drug Saf 2017; 26 : 1-8.

60 Avong YK, Isaakidis P, Hinderaker SG, et al. Doing no harm? Adverse events in a nation-wide cohort of patients with multidrug-resistant tuberculosis in Nigeria. PLoS One 2015; 10: e0120161.

61 Oreagba IA, Oshikoya KA, Ogar C, et al. Adverse reactions to fluoroquinolones in the Nigerian population: an audit of reports submitted to the National Pharmacovigilance Centre from 2004 to 2016. Pharmacol Res Perspect 2017; 5: e00297.

62 Halleux CM, Falzon D, Merle C, et al. The World Health Organization global aDSM database: generating evidence on the safety of new treatment regimens for drug-resistant tuberculosis. Eur Respir J 2018; 51 : 1701643.

63 Silva DR, Rendon A, Alffenaar JW, et al. Global TB Network: working together to eliminate tuberculosis. J Bras Pneumol 2018; 44: 347-349.

64 Akkerman O, Aleksa A, Alffenaar JW, et al. Surveillance of adverse events in the treatment of drug-resistant tuberculosis: a global feasibility study. Int J Infect Dis 2019; 83: 72-76.

65 Skrahina A, Hurevich H, Viatushka D, et al. Active drug-safety monitoring and management for tuberculosis patients treated with bedaquiline and linezolid, Belarus - 2014-2016. Eur Respir J 2016; 48: Suppl. 60, PA2682.

66 Skrahina A, Hurevich H, Falzon D, et al. Bedaquiline in the multidrug-resistant tuberculosis treatment: Belarus experience. Int J Mycobacteriol 2016; 5: Suppl. 1, S62-SS3.

67 Bastard M, Molfino L, Mutaquiha C, et al. Treatment outcomes of patients switching from an injectable drug to bedaquiline during short standardized MDR-TB treatment in Mozambique. Clin Infect Dis 2019; https://doi.org/ $10.1093 / \mathrm{cid} / \mathrm{ciz} 196$

68 Hafkin J, Hittel N, Martin A, et al. Early outcomes in MDR-TB and XDR-TB patients treated with delamanid under compassionate use. Eur Respir J 2017; 50: 1700311.

69 Sarin R, Singla N, Vohra V, et al. Initial experience of bedaquiline implementation under the National TB Programme at NITRD, Delhi, India. Indian J Tuberc 2019; 66: 209-213.

70 Sarin R, Vohra V, Singla N, et al. Early efficacy and safety of bedaquiline and delamanid given together in a "salvage regimen" for treatment of drug-resistant tuberculosis. Indian J Tuberc 2019; 66: 184-188.

71 Kelly AM, Smith B, Luo Z, et al. Discordance between patient and clinician reports of adverse reactions to MDR-TB treatment. Int J Tuberc Lung Dis 2016; 20: 442-447.

72 Avong YK, Jatau B, Gurumnaan R, et al. Addressing the under-reporting of adverse drug reactions in public health programs controlling HIV/AIDS, tuberculosis and malaria: a prospective cohort study. PloS One 2018; 13: e0200810.

73 Guglielmetti L, Hewison C, Avaliani Z, et al. Examples of bedaquiline introduction for the management of multidrug-resistant tuberculosis in five countries. Int J Tuberc Lung Dis 2017; 21: 167-174.

74 Furin J, Brigden G, Lessem E, et al. Global progress and challenges in implementing new medications for treating multidrug-resistant tuberculosis. Emerging Infect Dis 2016; 22: e151430.

75 Challenge TB. Generic Programmatic and Clinical Guide for Introduction of New Drugs and Shorter Regimens for Treatment of M/XDR-TB. Version 20. The Hague, KNCV Tuberculosis Foundation, 2017. 